\title{
Correction to: Preservice science teachers' emerging pedagogy of mobile game integration: a tale of two cohorts improvement study
}

\author{
Phattaraporn Pondee ${ }^{1}$, Patcharin Panjaburee ${ }^{2}$ and Niwat Srisawasdi ${ }^{{ }^{*}}$ (])
}

The original article can be found online at https://doi. org/10.1186/s41039-02100152-0.

\section{*Correspondence:}

niwsri@kku.ac.th

${ }^{1}$ Faculty of Education, Khon

Kaen University, Khon Kaen, Thailand

Full list of author information is available at the end of the article

\section{Correction to:Research and Practice in Technology Enhanced Learning (2021) 16:16 https://doi.org/10.1186/s41039-021-00152-0}

Following publication of the original article Pondee et al. (2021), it was found that all authors' first name and family name are interchanged.

The correct author names are:

Phattaraporn Pondee, Patcharin Panjaburee and Niwat Srisawasdi.

The original paper has been updated.

Author details

${ }^{1}$ Faculty of Education, Khon Kaen University, Khon Kaen, Thailand. ${ }^{2}$ Institute for Innovative Learning, Mahidol University, Salaya, Thailand.

Published online: 02 September 2021

\section{Reference}

Pondee, P., et al. (2021). Preservice science teachers' emerging pedagogy of mobile game integration: A tale of two cohorts improvement study. Research and Practice in Technology Enhanced Learning, 16, 16. https://doi.org/10.1186/ s41039-021-00152-0

\section{Publisher's Note}

Springer Nature remains neutral with regard to jurisdictional claims in published maps and institutional affiliations. author(s) and the source, provide a link to the Creative Commons licence, and indicate if changes were made. The images or other third party material in this article are included in the article's Creative Commons licence, unless indicated otherwise in a credit line to the material. If material is not included in the article's Creative Commons licence and your intended use is not permitted by statutory regulation or exceeds the permitted use, you will need to obtain permission directly from the copyright holder. To view a copy of this licence, visit http:// creativecommons.org/licenses/by/4.0/. 